\section{Cureus}

Received 07/11/2018

Review began $07 / 17 / 2018$

Review ended 07/17/2018

Published 07/22/2018

\section{(C) Copyright 2018}

Fransawy Alkomos et al. This is an open access article distributed under the terms of the Creative Commons Attribution License CC-BY 3.0., which permits unrestricted use, distribution, and reproduction in any medium, provided the original author and source are credited.

\title{
Age Limit and Radiotherapy Option for Sarcomatoid Carcinoma of the Larynx: A Case Report with Literature Review
}

Mina Fransawy Alkomos ${ }^{1}$, Michael Rizk ${ }^{2}$, Goubran Eskander ${ }^{2}$, Ahmed Elkheshen ${ }^{3}$, Rupak Mahendhar ${ }^{4}$, Amir Shahbaz ${ }^{4}$, Paria Zarghamravanbakhsh ${ }^{5}$, Phoebe Younan ${ }^{6}$, Nasim Golchin ${ }^{7}$, Issac Sachmechi ${ }^{4}$

1. Research, California Institute of Behavioral Neurosciences \& Psychology, Sacramento, USA 2. Otolaryngology, Ain Shams University, Cairo, EGY 3. Internal Medicine, The Icahn School of Medicine at Mount Sinai, New York, USA 4. Internal Medicine, Icahn School of Medicine at Mount Sinai/Queens Hospital Center, New York, USA 5. Endocrinology, Icahn School of Medicine at Mount Sinai Queens Hospital Center, New York, USA 6. Faculty of Medicine, Ain Shams University, Cairo, EGY 7. Endocrinology, Icahn School of Medicine at Mount Sinai/Queens Hospital Center, New York, USA

$\square$ Corresponding author: Mina Fransawy Alkomos, minafransawyalkomos@gmail.com Disclosures can be found in Additional Information at the end of the article

\section{Abstract}

Sarcomatoid carcinomas, also known as spindle cell carcinomas (SPCCs), are rare carcinomas, predominantly developing in the lung. They have lots of features of sarcoma in their histological features. The standard laryngeal carcinoma classification is based on tumor size, lymph node affection, and metastasis (TNM), it is the classification scheme of the American Joint Committee on Cancer Staging (AJCC), and it is used in the same way for stage spindle cell carcinoma (SPCC). We present a case report of a young female along with a literature review of sarcomatoid carcinoma of the larynx.

Categories: Otolaryngology, Oncology

Keywords: carcinosarcoma, spindle cell carcinomas, laryngeal sarcomatoid carcinoma

\section{Introduction}

Sarcomatoid carcinomas, also known as spindle cell carcinomas (SPCC), are rare carcinomas that predominantly develop in the lung. They have lots of features of sarcomas in their histological features [1-3]. In the larynx, sarcomatoid carcinomas are considered high-grade variants of squamous cell carcinomas, with no randomized clinical trials, conducted to specify a treatment modality [2]. The standard laryngeal carcinoma classification scheme of the American Joint Committee on Cancer Staging (AJCC) is used in the same way as to stage SPCC [3]. The classification is based on tumor size, lymph node affection, and metastasis (TNM) [3]. Most laryngeal SPCCs give symptoms early, predominantly hoarseness of voice. The reason for hoarseness of voice is that they most commonly appear as glottic pedunculated polypoidal masses (T1 or T2 lesions) with minimal invasion of the underlying stroma. The presenting gross appearance allows early wide complete transoral local excisions [3]. Scholars suggested good disease-controlled outcomes for early-stage glottic sarcomatoid carcinomas when treated with irradiation, comparing favorably with early glottic squamous cell carcinomas [4].

\section{Case Presentation}

\section{How to cite this article}

Fransawy Alkomos M, Rizk M, Eskander G, et al. (July 22, 2018) Age Limit and Radiotherapy Option for Sarcomatoid Carcinoma of the Larynx: A Case Report with Literature Review. Cureus 10(7): e3023. DOI 10.7759 /cureus.3023 


\section{Cureus}

A 24-year-old female patient presented to the otolaryngology clinic with a six-month history of progressive hoarseness of voice. In addition, she has a recent history of mild dyspnea on exertion and dry cough. The patient did not have any weight loss nor dysphagia. The patient was a cigarette smoker of around one pack per day for five years. There was no past family history of cancer, and she did not have any medical illness of significance. The patient also did not have any prior history of radiotherapy. In the clinic, fiberoptic nasoendoscopy showed a right vocal fold mass reaching the anterior commissure. The vocal fold mobility was normal. The neck examination was unremarkable. Our clinical impression, at this stage, was that the patient had early glottic laryngeal cancer. Consequently, the patient had a computed tomography (CT) scan showing the mass with no cervical lymphadenopathy (Figure 1).

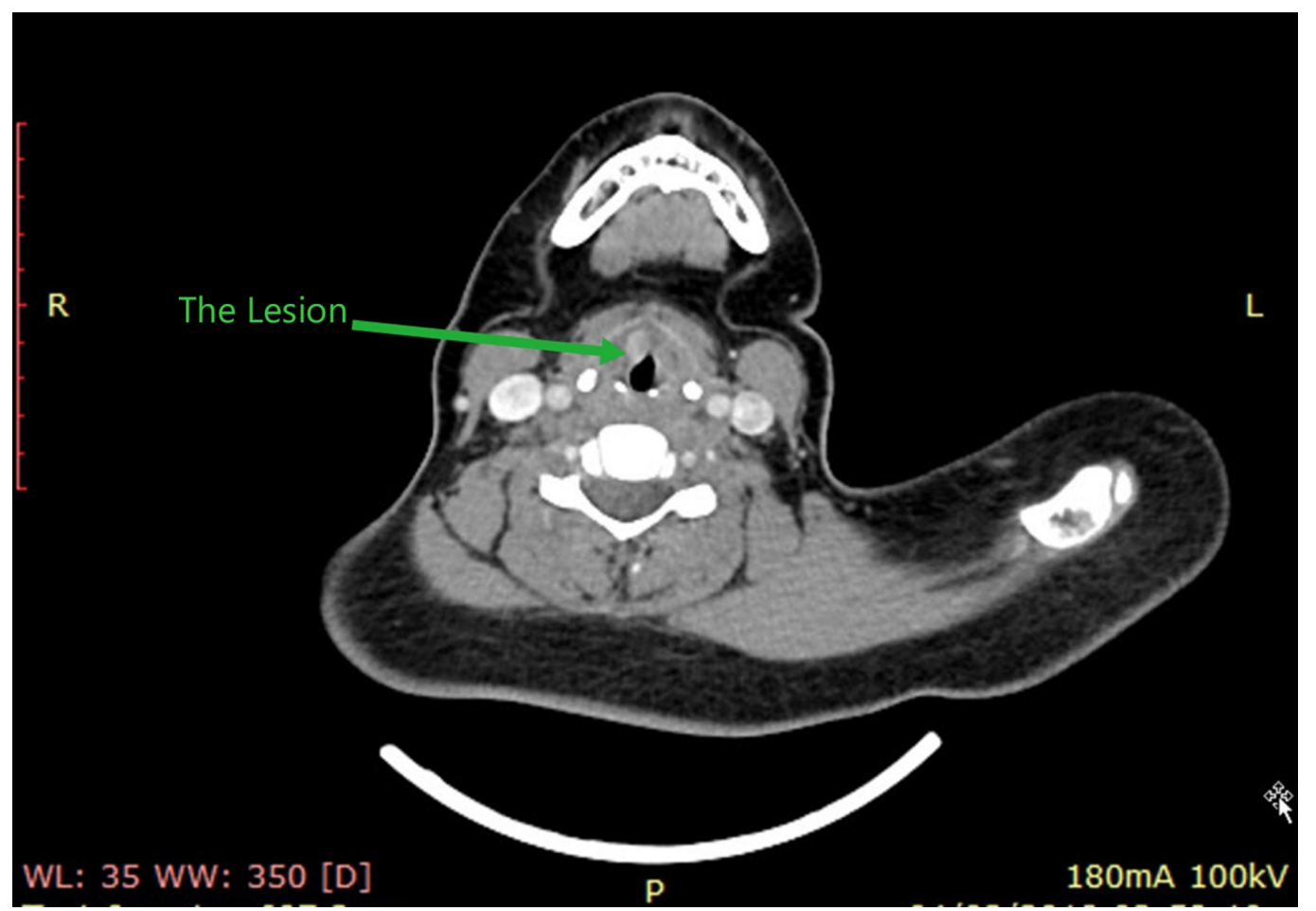

FIGURE 1: CT scan findings: A lesion at the glottic level, without any lymphadenopathy.

CT: computed tomography

The vocal fold mobility was normal. The neck examination was unremarkable. The patient underwent a laryngotracheoscopy under general anesthetic, with a biopsy taken from the lesion, which appeared to be arising from the right vocal fold without a subglottic extension. The initial histopathology report confirmed sarcomatoid carcinoma and subsequent immunohistochemistry was positive for epithelial membrane antigens (EMA), cytokeratin CK 5/6, and cytokeratin AE1/AE3AE 1/3 (Figures 2-4). 


\section{Cureus}

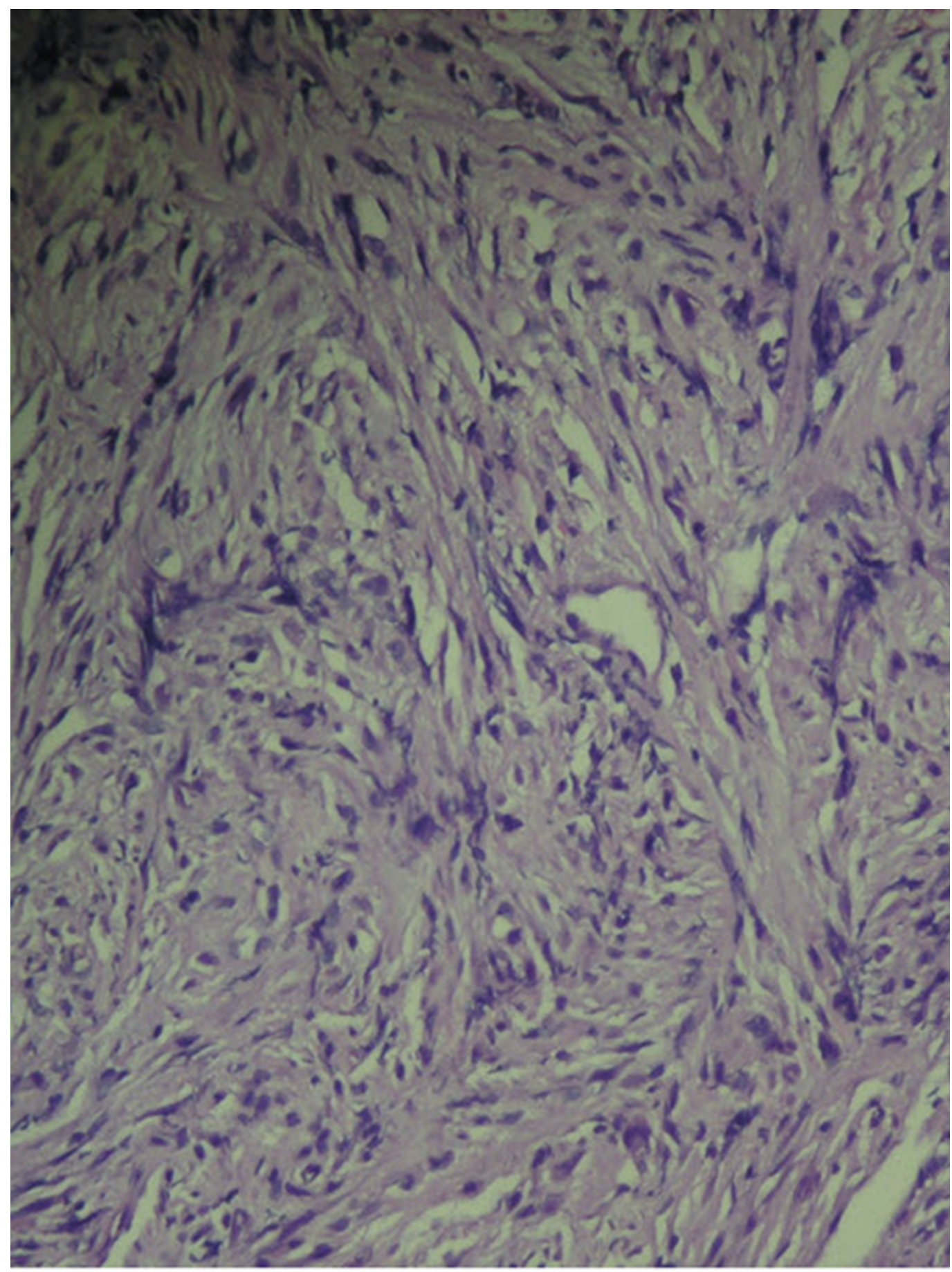

FIGURE 2: Histopathology stained with H\&E: Spindle cells with short fascicles and pleomorphic nuclei. 


\section{Cureus}

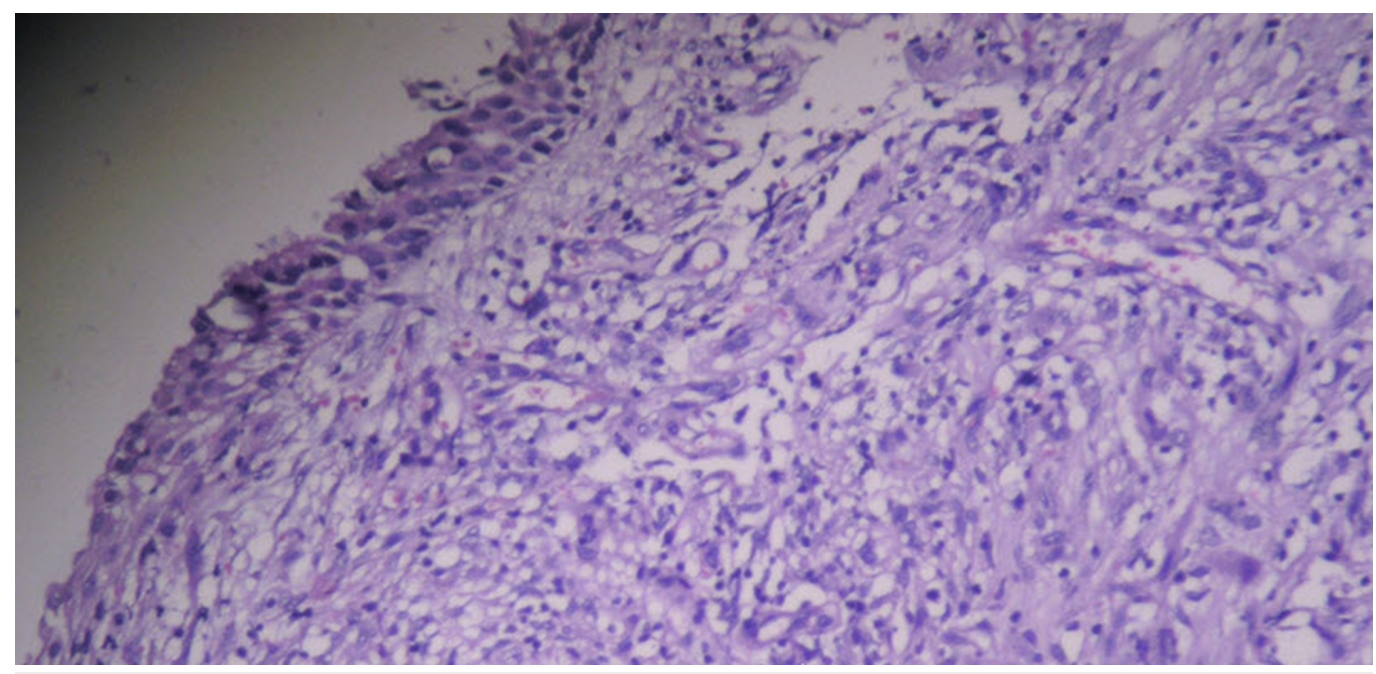

FIGURE 3: Histopathology: Cells eroding mildly dysplastic epithelium.

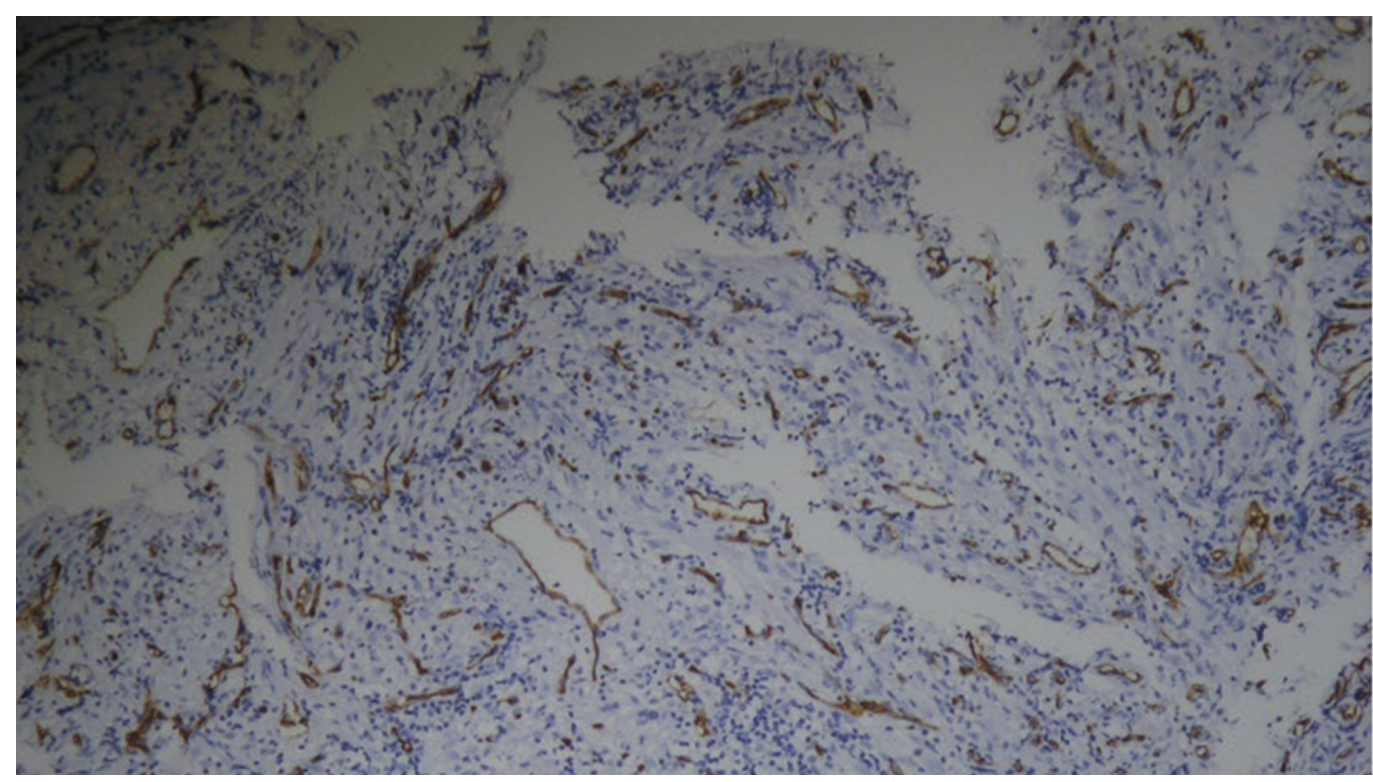

FIGURE 4: Histopathology: CD34 positive internal control and negative in tumor cells.

The patient's spindle cell (sarcomatoid) carcinoma stage was T2NOM0 according to the AJCC cancer staging system for laryngeal carcinomas. The options for management were evaluated by the head and neck multidisciplinary team, who preferred a transoral surgical excision as a modality of treatment. We discussed the treatment options with the patient, who refused surgical intervention. Consequently, she received intensity-modulated radiotherapy (IMRT). The patient had followed up at a six-month interval, and she remains free of the disease (Figure $5)$. 


\section{Cureus}

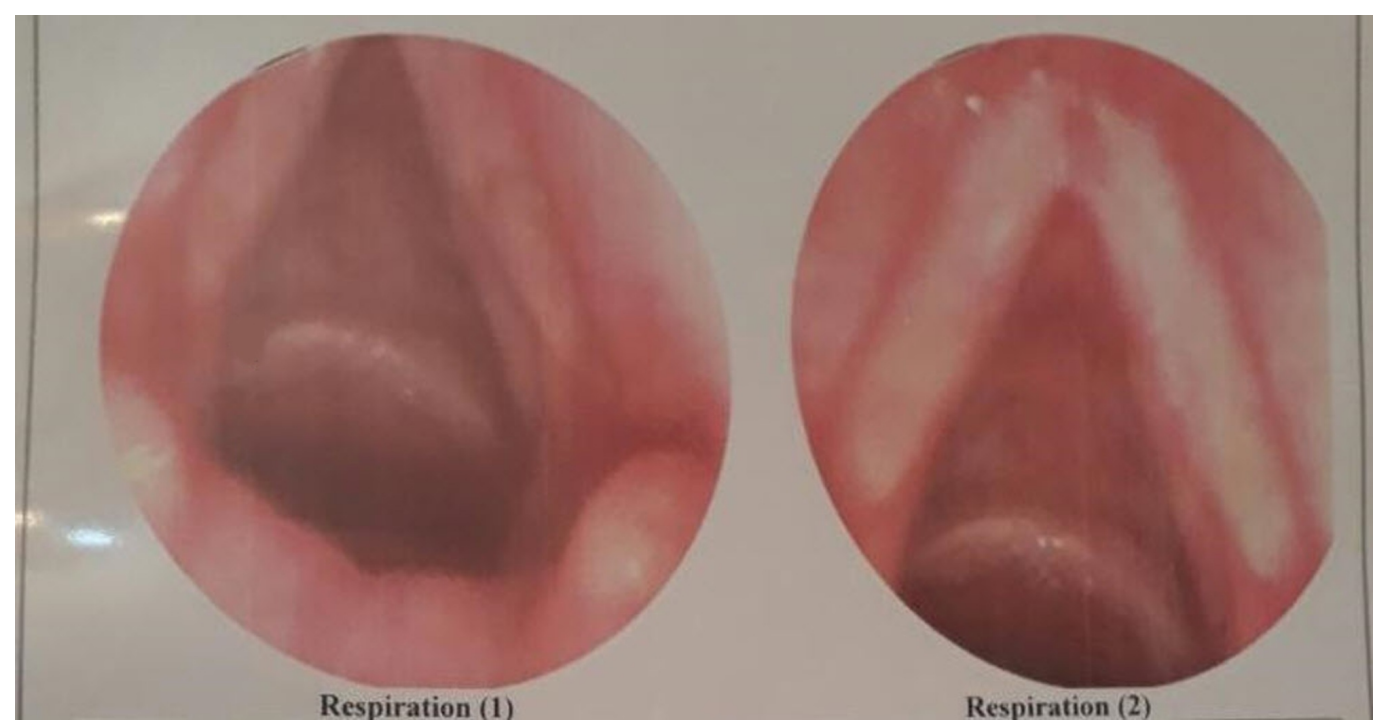

FIGURE 5: Follow-up by laryngoscope after six months showed no recurrence. Respiration (1) shows the posterior commissure and respiration (2) shows the anterior commissure.

\section{Discussion}

\section{Methods}

We also conducted a review of the literature based on a search performed on June 9, 2018, in PubMed. We discovered 167 articles, and on further screening, we excluded 103 articles, as they were not related to our topic or we could not download it. Then, 49 studies were excluded in the full-text analysis due to irrelevant disease. Fifteen articles were included in our review of the literature. We reviewed 59 patients with laryngeal carcinosarcoma having different ages, sexes, and modalities of carcinosarcoma treatment. The following table illustrates the review of the included patients (Table 1).

\begin{tabular}{|c|c|c|c|c|c|c|c|}
\hline ID & Article & $\begin{array}{l}\text { Age } \\
\text { (Years) } \\
\text { /Gender }\end{array}$ & $\begin{array}{l}\text { Specific Habits/ } \\
\text { Symptoms/Duration }\end{array}$ & Site/Classification & Treatment & Pathology Report of Surgical Specimen & $\begin{array}{l}\text { Subsequent } \\
\text { course/Follow-Up }\end{array}$ \\
\hline & & $58 / \mathrm{M}$ & $\begin{array}{l}\text { Smoker/hoarseness } \\
\text { for two Mo }\end{array}$ & $\begin{array}{l}\text { Rt anterior } \\
\text { commissure/T1bNOM0 }\end{array}$ & Local excision & Pseudo-Sarcocarcinoma in situ & $\begin{array}{l}\text { Neck metastasis four } \\
\text { Mo, and FOD eight } Y \\
\text { later }\end{array}$ \\
\hline & & $56 / \mathrm{M}$ & $\begin{array}{l}\text { Smoker/hoarseness } \\
\text { for two Wks }\end{array}$ & $\begin{array}{l}\text { Lt anterior } \\
\text { commissure/ T2N1M0 }\end{array}$ & SSL & $\begin{array}{l}\text { Carcinoma in situ and invasive epidermoid } \\
\text { carcinoma pseudo sarcoma }\end{array}$ & $\begin{array}{l}\text { Neck metastasis nine } \\
\text { Mo, It RND, one node } \\
\text { has cancer/FOD four M0 } \\
\text { before death from MI }\end{array}$ \\
\hline & & $43 / \mathrm{F}$ & $\begin{array}{l}\text { Smoker/hoarseness } \\
\text { for four Mo }\end{array}$ & Lt TVC/T1aNOMO & Lt HL & $\begin{array}{l}\text { Invasive epidermoid carcinoma with } \\
\text { underlying pseudosarcoma }\end{array}$ & FOD nine and a half $\mathrm{Y}$ \\
\hline & Randall et & 74/M & $\begin{array}{l}\text { Smoker/hoarseness } \\
\text { for one } Y\end{array}$ & $\begin{array}{l}\text { Anterior } \\
\text { commissure/T2NOMO }\end{array}$ & Frontal HL & Pseudosarcoma & FOD four $Y$ \\
\hline
\end{tabular}




\section{Cureus}

1 al. [5]

60/M

Smoker/hoarseness

for three Mo

Smoker/hoarseness

67/M

for one Mo

$55 / \mathrm{M}$

Dysphagia for three

Mo

80/F

Dysphagia for eight Mo

$80 / \mathrm{M}$

Dysphagia for three

Smoker/hoarseness

$62 / \mathrm{M}$

for one Y/dyspnea

for one wk

Smoker/hoarseness

for three M/otalgia

Anterior half of Lt VC

HL

L

bilateral/T3N1M0

Epiglottis rt T3N1M0

SSL, Bilateral RND

Pseudosarcoma

Died with cancer three $Y$

Lt AE/ T3NOMO

SSL, LT RND

TL

Pseudosarcoma

Died with cancer 13 M0

Local recurrence, 10

Mo/died one and a half

SCC with sarcoma-like areas

FOD $15 \mathrm{Y}$

Local recurrence,

Hoarseness for three

Base of the epiglottis $\quad R d$

Right arytenoid

Hoarseness for three

$56 / M$

mo

Left true cord

None

cord

Appelma

$59 / \mathrm{M}$

Difficulty swallowing

for six mo

ypopharynx, false

Rd then local

Dysphagia for seven

Mo

Right, true cord

Hoarseness (nine

$42 / \mathrm{M}$

mo) neck pain (one

Right, true cord

HL

Mo)

Hoarseness for two

$59 / \mathrm{M}$

yr, dysphagia for

Both true cords and

three Mo.

commissure

thens,

dysphagia, weight

loss, six Wks

Right ventricular fold

lymph node metastasis, Fusion of SCC and spindle cells

10 Mo followed by
Fusion of SCC and spindle cells

Snare excision

+radiotherapy

None

recurrence, Four yr.

total laryngectomy

Fusion of SCC and spindle cells

SCC intermixed with spindle cells; osteoid

and chondroid areas

Predominant bizarre spindle cell neoplasm

SCC intermixed with spindle cells; osteoid

and chondroid areas

SCC intermixed with spindle cells; osteoid

metaplasia

Died, five and a half

$\mathrm{Y}$, cervical node

metastasis

Alive and ell after $13.5 \mathrm{Y}$

recurrence, cervical

radiotherapy

Five Mo, radium

implant/died 14 months

ate

Cervical node

metastasis, one Mo/died

two and a half $Y$

Died five mo

Died eight Mo

TL/Metastasis in

cervical lymph nodes,

Fusion of SCC and spindle cells

Died, 10 Mo

Died two and a half $Y$

ater

FOD one and a half 


\section{Cureus}

\begin{tabular}{|c|c|c|c|c|c|c|c|}
\hline & & 77/M & mo & Right, true cord & TL & SCC with demarcated sarcoma-like areas & year later \\
\hline 3 & $\begin{array}{l}\text { Katholm } \\
\text { et al. [6] }\end{array}$ & $50 / \mathrm{M}$ & Smoker/hoarseness & LT VC/T1ANOM0 & Radiotherapy & $\begin{array}{l}\text { Interlacing bundles of large spindle-shaped } \\
\text { cells with pleomorphic nuclei and nucleoli. }\end{array}$ & FOD $22 \mathrm{Mo}$ \\
\hline 4 & $\begin{array}{l}\text { Alguacil- } \\
\text { Garcia et } \\
\text { al. [7] }\end{array}$ & 59/M & $\begin{array}{l}\text { Smoker/hoarseness } \\
\text { for one year }\end{array}$ & Rt VC & TL & Sarcomatoid carcinoma & FOD two Y \\
\hline \multirow{14}{*}{5} & \multirow{14}{*}{$\begin{array}{l}\text { Hellquist } \\
\text { et al. [8] }\end{array}$} & 64/M & $\begin{array}{l}\text { Hoarseness of voice } \\
\text { for seven Mo }\end{array}$ & VC & TL & SPCC & \\
\hline & & $66 / F$ & $\begin{array}{l}\text { Hoarseness of voice } \\
\text { for eight Mo }\end{array}$ & Epiglottis & Rad & SPCC & FOD three and a half $Y$ \\
\hline & & $54 / \mathrm{M}$ & $\begin{array}{l}\text { Hoarseness of voice } \\
\text { for three Mo }\end{array}$ & VC & TL & SPCC & FOD three $Y$ \\
\hline & & 69/M & $\begin{array}{l}\text { Hoarseness of voice } \\
\text { for four Mo }\end{array}$ & VC & Excision, rad & SPCC & FOD one and a half $Y$ \\
\hline & & 71/M & $\begin{array}{l}\text { Hoarseness of voice } \\
\text { for two Mo }\end{array}$ & VC & $\begin{array}{l}\text { Rad/then recurrence } \\
\text { after five } Y \text {, then } \\
\text { laryngofissure }\end{array}$ & SPCC & FOD eight and a half $Y$ \\
\hline & & $62 / F$ & $\begin{array}{l}\text { Hoarseness of voice } \\
\text { for three Mo }\end{array}$ & VC & Excision & SPCC & FOD one and a half $Y$ \\
\hline & & $57 / \mathrm{M}$ & $\begin{array}{l}\text { Hoarseness of voice } \\
\text { for four Mo }\end{array}$ & VC & TL+Radio & SPCC & FOD one and a half $Y$ \\
\hline & & $36 / \mathrm{M}$ & $\begin{array}{l}\text { Hoarseness of voice } \\
\text { for four Mo }\end{array}$ & Subglottis & Excision + Radio & SPCC & FOD three Y \\
\hline & & 63/M & $\begin{array}{l}\text { Hoarseness of voice } \\
\text { for five Mo }\end{array}$ & VC & Radio & SPCC & FOD two Y \\
\hline & & 75/F & $\begin{array}{l}\text { Hoarseness of voice } \\
\text { for six Mo }\end{array}$ & VC & Radio & SPCC & $\begin{array}{l}\text { LNs metastasis After } \\
\text { one } Y \text { died with the ds } \\
\text { after three } Y\end{array}$ \\
\hline & & 59/M & $\begin{array}{l}\text { Hoarseness of voice } \\
\text { for three and a half } \\
\text { Mo }\end{array}$ & VC & Radio & SPCC & FOD $11.5 \mathrm{Y}$ \\
\hline & & 67/M & $\begin{array}{l}\text { Hoarseness of voice } \\
\text { for two and a half Mo }\end{array}$ & VC & Excision+radio & SPCC & FOD six Y \\
\hline & & 57/M & $\begin{array}{l}\text { Hoarseness of voice } \\
\text { for two Mo }\end{array}$ & VC & Excision & SPCC & FOD $10.5 \mathrm{Y}$ \\
\hline & & 69/M & $\begin{array}{l}\text { Hoarseness of voice } \\
\text { for two Mo }\end{array}$ & VC & Excision & SPCC & FOD five $Y$ \\
\hline 6 & $\begin{array}{l}\text { Lassaletta } \\
\text { et al. [9] }\end{array}$ & $48 / F$ & $\begin{array}{l}\text { Smoke } 40 \text { Cig/day/ } \\
\text { hoarseness and } \\
\text { intermitted stridor }\end{array}$ & Lt VC & $\begin{array}{l}\text { Functional neck } \\
\text { dissection and total } \\
\text { laryngectomy }\end{array}$ & $\begin{array}{l}\text { GCT Lt VC/SPCC in subglottic/positive for } \\
\text { EMA, cytokeratin CK } 5 / 6 \text { and cytokeratin } \\
\text { AE1/AE3AE } 1 / 3 \text {, keratin } 8 \text {, anion exchange }\end{array}$ & FOD six Mo \\
\hline
\end{tabular}




\section{Cureus}

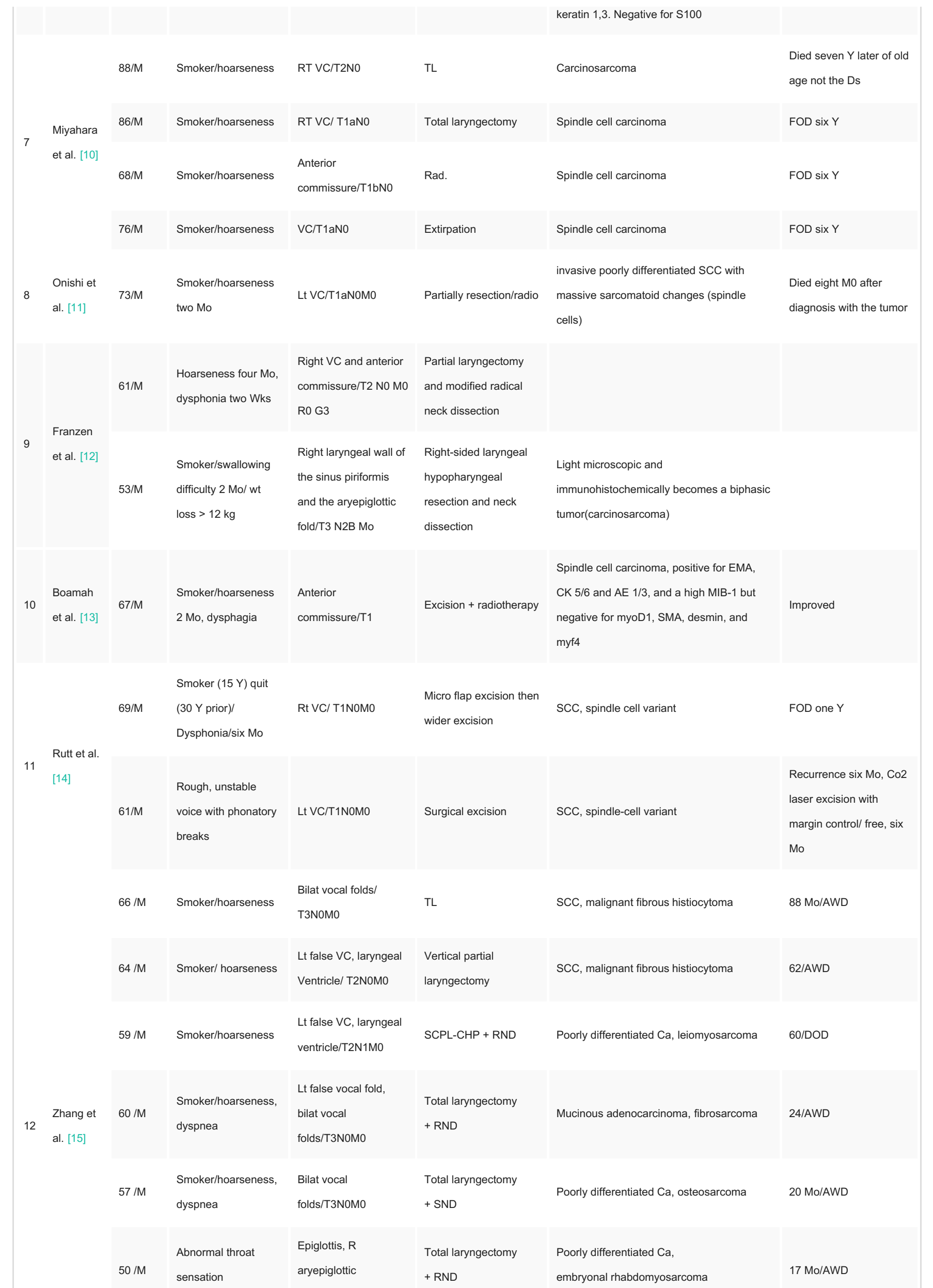




\section{Cureus}

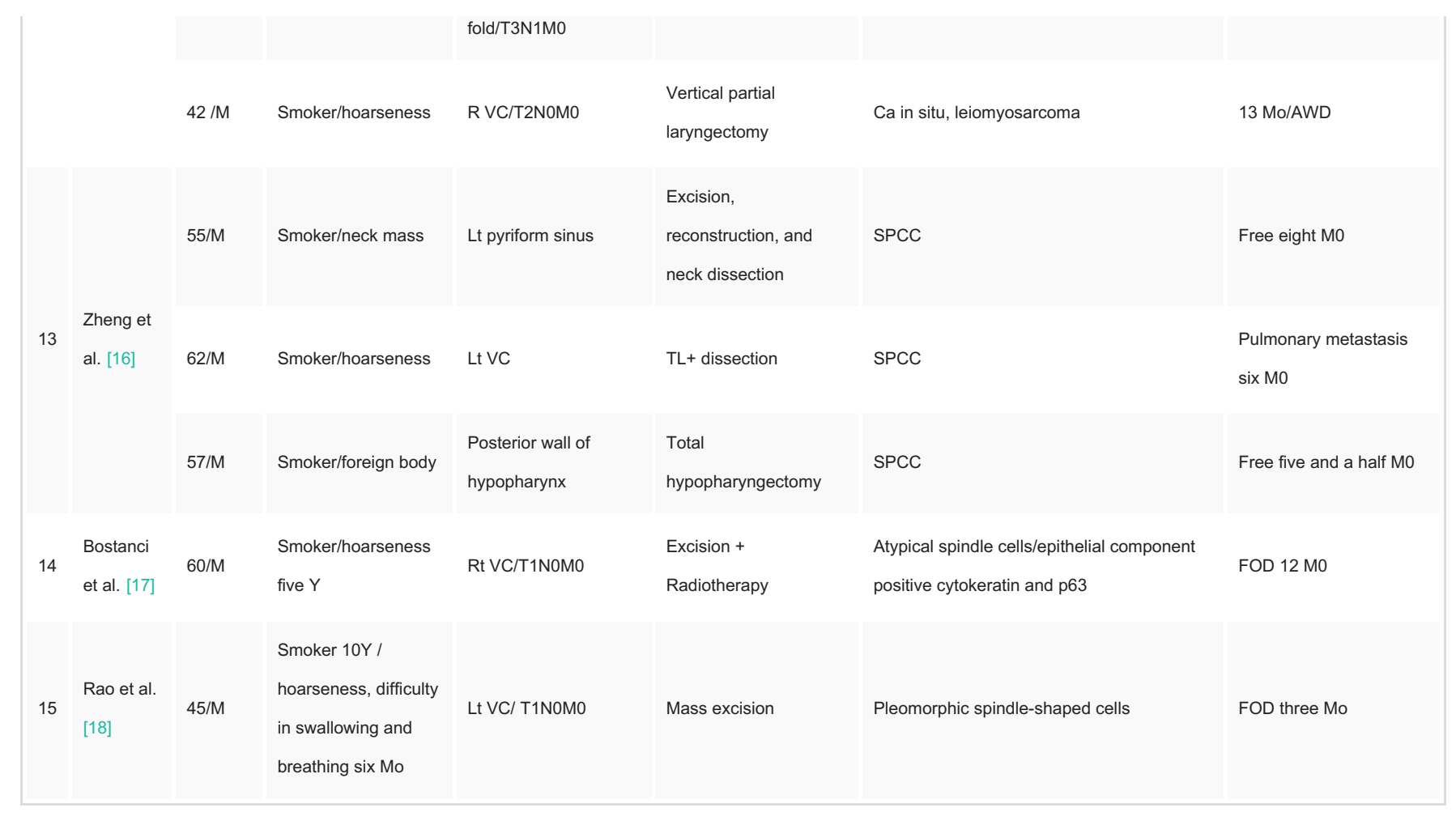

\section{TABLE 1: Clinical characteristics of patients with laryngeal sarcomatoid carcinoma}

described in the literature $(n=59)$

$\mathrm{M}=$ Male, $\mathrm{F}=$ Female, $\mathrm{Mo}=$ month $\mathrm{Rt}=$ right, $\mathrm{Lt}=$ left, FOD: free of disease, $\mathrm{VC}=$ vocal cord, $\mathrm{SCC}=$ squamous cell carcinoma, SPCC $=$ spindle cell carcinoma, $\mathrm{Y}=$ year, GCT $=$ Giant cell tumor, EMA = Epithelial membrane antigen, Ds $=$ Disease, Rad. $=$ Radiotherapy, TL = Total laryngectomy, RND = Radical neck dissection, SSL = Subtotal supraglottic laryngectomy, SCPL-CHP = Suprecricoid partial laryngectomy. pseudosarcoma, indicating the view that the spindle-shaped cells are reactive rather than neoplastic.

\section{Results}

The included articles described a total of 59 patients, 52 of which were males and seven were females. The age range was between 36 and 88 years. The reported cases were from 1960 till 2016. Most of the patients were smokers, and most of them underwent total laryngectomy followed by radiotherapy. On the other hand, eight patients received radiotherapy only, while the rest had different types of surgery. The general survival outcome was better with a combination of both surgery and radiation, compared to radiotherapy alone.

\section{Discussion}

Carcinosarcoma is a rare lesion; it can be present in many body parts, including the larynx. The larynx appears to be an unusual site, as only a few cases can be found in the literature. Carcinosarcoma is considered a malignant tumor composed of both epithelial and mesenchymal components. It accounts for less than $1 \%$ of all malignant tumors of the larynx and hypopharynx [19]. In our review of the literature, we noticed that there is a broad age range for laryngeal carcinosarcoma (36-88 years), while our case was 24 years old. Despite being a rare condition, spindle cell carcinoma should be considered a valid diagnosis in any age group, especially if the patient presents with hoarseness of voice or dyspnea and a history of smoking. Surgical intervention was the first line of management in the treatment of most of the laryngeal carcinosarcomas mentioned in our literature with a favored outcome. However, scholars suggested good disease-controlled results for early-stage glottic sarcomatoid 
carcinomas when treated with irradiation, comparing favorably with early glottic squamous cell carcinomas [4]. We had eight patients in our review that received radiotherapy only, without any surgical intervention $[2,6,8,10\}$. These patients had different ages, cancer stages, and laryngeal cancer locations. Five out of the eight patients who were treated only with radiation have no evidence of the disease at a range of two to 11.5 years while the other three developed a recurrence and died of the disease later on. So radiotherapy might be a valid alternative option instead of surgical therapy in selected patients. Our patient has stage T2N0M0 glottic carcinoma. Due to the early detection of the tumor and its site, the surgical excision was a valid and reasonable option for management. However, the patient preferred the radiotherapy option. The follow-up plan will be the same as for other glottic carcinomas.

\section{Conclusions}

Spindle cell carcinoma (SPCC) or sarcomatoid carcinoma of the larynx is a rare, highly malignant variant of squamous cell carcinoma. It can present at an early age with symptoms and diagnosis is possible in the early stages. Although in some patients, surgery is the best modality of therapy, radiation only can be a reasonable alternative.

\section{Additional Information \\ Disclosures}

Human subjects: Consent was obtained by all participants in this study. Conflicts of interest: In compliance with the ICMJE uniform disclosure form, all authors declare the following:

Payment/services info: All authors have declared that no financial support was received from any organization for the submitted work. Financial relationships: All authors have declared that they have no financial relationships at present or within the previous three years with any organizations that might have an interest in the submitted work. Other relationships: All authors have declared that there are no other relationships or activities that could appear to have influenced the submitted work.

\section{References}

1. Travis WD, Brambilla E, Müller-Hermelink HK, Harris CC: Tumors of the Lung, Pleura, Thymus, and Heart. World Health Organization Classification of Tumours. IARC Press, 2004.

2. Appleman HD, Oberman HA: Squamous cell carcinoma of the larynx, with sarcoma-like stroma. A Clinical-Pathological assessment of spindle cell carcinoma and pseudosarcoma. AJCP. 1965, 44(2):135-145. 10.1093/ajcp/44.2.135

3. El-Naggar AK, Chan JKC, Takata T, Grandis JR, Slootweg PJ: The fourth edition of the head and neck World Health Organization blue book: editors' perspectives. Hum Pathol. 2017, 66:10-12. 10.1016/j.humpath.2017.05.014

4. Ballo MT, Garden AS, El-Naggar AK, Gillenwater AM, Morrison WH, Goepfert H, Ang KK: Radiation therapy for early stage (T1-T2) sarcomatoid carcinoma of true vocal cords: outcomes and patterns of failure. Laryngoscope. 2009, 108:760-763. 10.1097/00005537199805000-00024

5. Randall G, Alonso WA, Ogura JH: Spindle cell carcinoma (pseudosarcoma) of the larynx . JAMA Otolaryngol Head Neck Surg. 1975, 101:63-66. 10.1001/archotol.1975.00780300067018

6. Katholm M, Krogdahl A, Hainau B, Bretlau P: Spindle cell carcinoma of the larynx . Acta Otolaryngol Case Rep. 1984, 98:163-166. 10.3109/00016488409107550

7. Alguacil-Garcia A, Alonso A, Pettigrew NM: Sarcomatoid carcinoma (so-called pseudosarcoma) of the larynx simulating malignant giant cell tumor of soft parts. Am J Clin Pathol. 1983, 82:340-343. 10.1093/ajcp/82.3.340

8. Hellquist H, Olofsson J: Spindle cell carcinoma of the larynx. APMIS. 1989, 97:1103-1113. 10.1111/j.1699-0463.1989.tb00524.x

9. Lassaletta L, Alonso S, Granell J, Ballestín C, Serrano A, Álvarez-Vicent JJ: Synchronous glottic granular cell tumor and subglottic spindle cell carcinoma. JAMA Otolaryngol Head 
Neck Surg. 1998, 124:1031-1034. 10.1001/archotol.124.9.1031

10. Miyahara H, Tsuruta Y, Yane K, Ogawa Y: Spindle cell carcinoma of the larynx. Auris Nasus Larynx. 2004, 31:177-182. 10.1016/j.anl.2004.01.008

11. Onishi H, Kuriyama K, Komiyama T, et al.: T1N0 laryngeal sarcomatoid carcinoma that showed rapid systemic metastases after radical radiotherapy: a case report and review of literature. Otolaryngol Head Neck Surg. 2005, 26:400-402. 10.1016/j.amjoto.2005.02.017

12. Franzen A, Theegarten D: Karzinosarkome des larynx und hypopharynx [Article in German]. Laryngorhinootologie. 2007, 86:209-212. 10.1055/s-2006-925440

13. Boamah H, Ballard B: A case report of spindle cell (sarcomatoid) carcinoma of the larynx . Case Rep Med. 2012, 2012:1-5. 10.1155/2012/370204

14. Rutt AL, Mintz I, Jackson-Menaldi C, Johns M, McHugh JB, Rubin AD: Spindle cell carcinoma of the larynx presenting as a vocal fold cyst. J Voice. 2014, 28:524.

10.1016/j.jvoice.2013.10.013

15. Zhang M, Zhao LM, Li XM, Zhou L, Lin L, Wang SY: True carcinosarcoma of the larynx . J Laryngol Otol. 2013, 127:100-103. 10.1017/S002221511200285X

16. Zheng Y, Xiao M, Tang J: Clinicopathological and immunohistochemical analysis of spindle cell carcinoma of the larynx or hypopharynx: a report of three cases. Oncol Lett. 2014, 8:748752. 10.3892/ol.2014.2172

17. Bostanci A, Ozbilim G, Turhan M: Spindle cell carcinoma of the larynx: a confusing diagnosis for the pathologist and clinician. Case Rep Otolaryngol. 2015, 2015:1-4. 10.1155/2015/831835

18. Rao BSS, Grandhi B, Shanthi V, Rao NM, Murthy BK: Carcinosarcoma of the larynx - a rare site entity. J Clin Diagn Res. 2016, 10:1-2. 10.7860/JCDR/2016/17174.7758

19. Luna-Ortiz K, Mosqueda-Taylor A: Supracricoid partial laryngectomy as a primary treatment for carcinosarcoma of the larynx. Ear Nose Throat J. 2006, 85:337-341. 